\title{
PEMILIHAN ENGINEERING CONTRACTOR PROYEK DANA HIBAH ENERGI TERBARUKAN DENGAN METODE DEMATEL DAN ANP (STUDI KASUS LEMBAGA “Y”)
}

\author{
Agus Setyo Pambudi \\ Magister Manajemen Teknologi ITS, Surabaya \\ a_setyo21@yahoo.com
}

\begin{abstract}
One of the success keys of the grant fund program for the renewable energy project is in the decision making process to find the engineering contractor with the best quality, effectiveness, and efficiency to implement the process of procurement of goods and services. The objective of this research is to design a systematic selection model for the engineering contractor referring to the conditions, situations, and scopes as required by the " $Y$ " institution. Data were processed using Decision Making Trial and Evaluation Laboratory (DEMATEL) and Analityc Network Process (ANP). The decision criteria referred to the PEPRES No. 70/2012, PERMEN No. 08/PRT/M/2011, and the results of Focus Group Discussion (FGD) conducted by the evaluation team. The assesments from the evaluation team were including internal and financial capability, technical capability, organizational capability, commitment to quality assurance, commitment to health and safety, and pricing.
\end{abstract}

Keywords: Selection of Engineering Contractor, Grant Fund, Renewable Energy, Decision Making Trial and Evaluation, Analytic Network Process.

\begin{abstract}
Abstrak: Salah satu kunci sukses program dana hibah proyek energi terbarukan adalah pada proses pengambilan keputusan untuk mendapatkan engineering contractor yang mempunyai kualitas, efektivitas, dan efisiensi yang baik sehingga proses pengadaan barang dan jasa dapat terlaksana. Tujuan penelitian ini adalah untuk merancang model pemilihan engineering contractor secara sistematis sesuai dengan kondisi, keadaan, dan ruang lingkup yang dipersyaratkan di lembaga "Y". Data penelitian diolah menggunakan DEMATEL dan ANP. Penentuan kriteria keputusan mengacu pada regulasi PEPRES No. 70/2012, PERMEN No. 08/PRT/M/2011, dan hasil kriteria dari FGD yang dilakukan oleh tim evaluasi. Penilaian oleh tim evaluasi meliputi kemampuan internal dan keuangan, kemampuan teknis, kemampuan organisasi, komitmen pada quality assurance, komitmen pada kesehatan dan keselamatan kerja, dan harga.
\end{abstract}

Kata Kunci: Pemilihan Engineering Contractor, Dana Hibah, Energi Terbarukan, Decision Making Trial and Evaluation, Analytic Network Process.

\section{Pendahuluan}

Penilaian kontraktor merupakan proses penting dalam membangun suatu proyek mulai dari tahap perencanaan, konstruksi sampai tahap operasi. Keberadaan sistem pemilihan engineering contractor yang ada di PEPRES No. 70/2012 dan Peraturan Kementerian Pekerjaan Umum No. 08/PRT/M/2011 di gunakan sebagai acuan bagi tim evaluasi Lembaga " $Y$ " dalam melakukan proses penilaian kompetensi dan kemampuan usaha serta pemenuhan persyaratan tertentu lainnya dari penyedia 
jasa. Pemilihan kontraktor menjadi salah satu proses krusial bagi pemilik proyek untuk dapat menyelesaikan proyek sesuai dengan permintaan. (Singh \& Tiong, 2005).

Kriteria yang menjadi pertimbangan dalam pengambilan keputusan evaluasi pemilihan engineering contractor di proyek Lembaga " $Y$ " sering kali memiliki keterkaitan satu dengan yang lain. Pengambilan keputusan multikriteria (Multiple Criteria Decision Making) adalah suatu metode proses pemilihan alternatif untuk mendapatkan solusi optimal dari beberapa alternatif keputusan dengan memperhitungkan kriteria atau objektif yang lebih dari satu yang berada dalam situasi yang bertentangan (conflicting).

Sedangkan menurut Swami. S (2013), dalam menentukan pilihannya, pengambil keputusan akan mempertimbangkan aspek positif dan negatif dari semua alternatif dan kemudian mempertimbangkannya untuk menentukan pilihan atau keputusan. Pengambilan keputusan adalah proses kognitif dalam memilih pilihan yang logis dari beberapa pilihan yang tersedia. Salah satu proses penting dalam proses evaluasi atau pemilihan kontraktor adalah penentuan kriteria keputusan yang akan digunakan oleh pengambil keputusan dalam melakukan penilaian terhadap kandidat kontraktor dan terdapat 2 faktor yang mempengaruhi penentuan kriteria pemilihan kontraktor, yaitu keinginan pemilik proyek (client objectives) dan persepsi pegambilan keputusan (decision-makerperceptions) (Ng, S. T., \& Skitmore, M, 1999).

DEMATEL yang pertama kali di kembangkan oleh The Science and Human Affairs Program of the Battelle Memorial Institute of Geneva antara tahun 1972-1976. Tujuan utama dikembangkannya DEMATEL adalah untuk mempelajari dan mencari penyelesaian permasalahan yang rumit dan saling berkaitan satu sama lain dengan konsep dasar mengukur tingkat pengaruh suatu objek dengan objek lainnya. Beberapa keunggulan yang dimiliki oleh model DEMATEL adalah sebagai berikut: (1) DEMATEL menyediakan pendekatan sistematis yang mengidentifikasi kriteria, hubungan antar kriteria, dan bobot masing-masing untuk pengambilan keputusan; (2) DEMATEL bisa digunakan untuk menjawab permasalahan inti dari system yang komplek dengan tujuan untuk memudahkan pengambilan keputusan.

Menurut Saaty T.L., (1994), Analytic Network Process (ANP) merupakan pengembangan dari metode Analytic Hierarchy Process (AHP) sebagai suatu teknik pengambilan keputusan yang dapat digunakan memilih sebuah keputusan yang kompleks. ANP dapat menggunakan teknik perbandingan berpasangan (pairwise comparison) dan pendapat ahli (expert judgement) untuk menentukan skala prioritas 
dari setiap kriteria keputusan dan penilaian terhadap alternatif keputusan (Saaty, 1999).

Sedangkan menurut Sevkli, et al. (2012), metode ANP dapat memperbaiki kekurangan metode ANP dalam mengakomodasi kompleksitas dalam sebuah model pengambilan keputusan dimana terdapat interaksi, interdependensi dan umpan balik (feedback) di antara kriteria-kriteria yang digunakan dalam sistem pengambilan keputusan. Proses pengambilan keputusan pada metode ANP terdiri dari 4 tahap, yaitu :

\section{a. Perancangan Model}

Pada tahap ini permasalahan diterjemahkan dalam bentuk struktur jaringan keputusan, yaitu dengan menentukan elemen kriteria dan sub-kriteria keputusan yang akan digunakan serta hubungan keterkaitan antar kriteria dan sub-kriteria tersebut.

\section{b. Perbandingan Berpasangan}

Elemen keputusan berupa kriteria atau sub-kriteria keputusan dan alternatif keputusan dibandingkan menggunakan metode perbandingan berpasangan dengan berdasarkan kriteria kontrol dan hubungan keterkaitan yang sudah didefinisikan dalam jaringan keputusan. Perbandingan berpasangan ini mengetahui pengaruh setiap elemen keputusan pada setiap kriteria kontrol dalam jaringan keputusan. Output dari tahap ini adalah tingkat kepentingan selektif dari elemen keputusan pada suatu kritera kontrol yang diperoleh dari masing-masing elemen.

\section{c. Perancangan Supermatriks}

Nilai tingkat kepentingan pada tahap sebelumnya disusun pada kolom matriks. Supermatriks merupakan sebuah matrik positif, dimana setiap elemen pada matriks tersebut mempresentasikan hubungan antara dua elemen dalam jaringan keputusan. Output dalam tahap ini adalah bobot kepentingan setiap elemen dalam jaringan keputusan.

\section{d. Sintesa Keputusan}

Pada tahap ini dilakukan normalisasi terhadap supermatrix dari tahap sebelumnya untuk memperoleh bobot kepentingan dari setiap elemen keputusan (kriteria dan alternatif keputusan). Bobot kepentingan tersebut kemudian disentesa menjadi nilai dari masing-masing alternatif keputusan yang sekaligus menjadi output dari metode ANP. Alternatif keputusan yang terbaik adalah alternatif dengan nilai tertinggi. 
Tujuan dari penelitian ini adalah untuk mengetahui kriteria yang menjadi prioritas pertimbangan Lembaga " $Y$ " dalam memilih engineering contractor yang qualified dan mengetahui prioritas engineering contractor dengan menganalisa hasil penilaian engineering contractor yang di peroleh dari metode DEMATEL dan pembobotan ANP.

\section{Metodologi}

Data dalam penelitian ini berasal dari kuisioner yang diberikan kepada tim evaluasi pemilihan engineering contractor yang akan digunakan untuk perhitungan kedua metode yaitu DEMATEL dan Analytic Networking Process (ANP). Dalam pengolahan DEMATEL ini terdapat beberapa tahap, mulai dari mencari matrik nilai Keterkaitan langsung antar kriteria, matrik nilai keterkaitan yang telah di normalkan dengan mengunakan rumus:

$$
\begin{aligned}
& X=k \cdot A \\
& k=\frac{1}{\max \left[\max _{1 \leq i \leq n} \sum_{j=1}^{n} a_{i j}, \max _{1 \leq j \leq n} \sum_{i=1}^{n} a_{i j}\right]}
\end{aligned}
$$

Keterangan:

$$
\begin{aligned}
& \mathrm{X}=\text { normalisasi matriks direct }- \text { relation } \\
& \mathrm{A}=\text { matriks direct }- \text { relation }
\end{aligned}
$$

Tahap-tahap pengolahan dengan metode DEMATEL secara rinci adalah sebagai berikut:

\section{a. Matrix Hubungan Langsung}

Dengan mengabungkan hasil rekap kuisioner kriteria dan subkriteria yang telah diisi para expert dengan menggunakan nilai rata-rata.

b. Penormalan Matrix

Melakukan penormalan pada matriks keterkaitan secara langsung dengan mengalikan nilai pada tiap kolom dengan nilai total dari jumlah nilai tiap baris.

c. Matrix Keterkaitan Total

Matrik keterkaitan total dapat dihitung dengan menggunakan 3 tahapan yaitu:

1. Melakukan pengurangan antara matrik identitas dengan matriks hasil penormalan. Matriks identitas yang digunakan untuk mengurangi matriks hasil penormalan harus memiliki jumlah kolom dari baris yang sama dengan matriks hasil penormalan. 
2. Melakukan perhitungan inversi dari matriks yang didapatkan dari hasil pengurangan matriks Identitas dengan matriks hasil penormalan. Matriks inversi dapat dihitung dengan menggunakan excel (MINVERSE)

3. Melakukan penjumlahan keterkaitan total dengan cara mengalikan matriks hasil penormalan dengan matriks invers. Hasil perkalian kedua matriks didapatkan dengan menggunakan Excel (MMULT).

d. Nilai Dispatcher dan Receiver

Data nilai Dispatcher dan Receiver didapat dari pengolahan matriks keterkaitan total. Nilai masing-masing kriteria harus dihitung dari sisi baris dan kolom. Nilai indeks total kekuatan pengaruh diberikan dan diterima oleh suatu kriteria/ subkriteria keputusan $(D+R)$, dan nilai kecenderungan tingkat pengaruh dari masingmasing kriteria / subkriteria keputusan (D-R).

e. Analisa Hubungan Antar Kriteria

Menurut Shieh (2010), threshold value didapatkan dari rata-rata seluruh nilai dari matriks T (Total Relation Matrix). Penentukan threshold value untuk mengetahui hubungan antara kriteria/subkriteria keputusan tersebut.

Hasil dari metode DEMATEL tersebut selanjutnya digunakan untuk menentukan bobot setiap kriteria dan subkriteria dari alternatif-alterrnatif yang ada dengan menggunakan metode Analytic Networking Process (ANP) dengan bantuan software Super Decision.

\section{Hasil dan Pembahasan}

Identifikasi Kriteria / Subkriteria keputusan dengan menggunakan FGD (Focus Group Discussion) oleh tim evaluasi Engineering Contractor dimana menghasilkan kriteria dan subkriteria seperti tabel 1. di bawah ini. 
Tabel 1: Hasil Identifikasi Kriteria/Subkriteria Keputusan

\begin{tabular}{|c|c|c|c|}
\hline Kriteria & Subkriteria & $\begin{array}{l}\text { Studi } \\
\text { Literatur }\end{array}$ & FGD \\
\hline \multirow{6}{*}{$\begin{array}{l}\text { Kemampuan Internal \& } \\
\text { Keuangan }\end{array}$} & Klasifikasi & - & $\checkmark$ \\
\hline & Kemampuan Keuangan & $\checkmark$ & $\checkmark$ \\
\hline & Reputasi & - & $\checkmark$ \\
\hline & Kemampuan Melaksanakan Paket & $\checkmark$ & $\checkmark$ \\
\hline & Kinerja Proyek Sebelumnya & $\checkmark$ & $\checkmark$ \\
\hline & Nilai Proyek Sejenis & - & $\checkmark$ \\
\hline \multirow{4}{*}{ Kemampuan Teknis } & Pengalaman Proyek yang sejenis & - & $\checkmark$ \\
\hline & Metode Pelaksanaan & $\checkmark$ & $\checkmark$ \\
\hline & Jadwal Pelaksanaan & $\checkmark$ & $\checkmark$ \\
\hline & Kapasitas Peralatan & $\checkmark$ & $\checkmark$ \\
\hline \multirow{4}{*}{ Kemampuan Organisasi } & Organisasi Proyek & $\checkmark$ & $\checkmark$ \\
\hline & Manajemen Proyek & $\checkmark$ & $\checkmark$ \\
\hline & SDM & $\checkmark$ & $\checkmark$ \\
\hline & Quality Control & $\checkmark$ & $\checkmark$ \\
\hline Quality Assurance & Komitmen pada Quality Assurance & - & $\checkmark$ \\
\hline $\begin{array}{l}\text { Keselamatan dan Kesehatan } \\
\text { Kerja }\end{array}$ & Komitmen pada $\mathrm{K} 3$ & $\checkmark$ & $\checkmark$ \\
\hline Harga & Harga Penawaran & $\checkmark$ & $\checkmark$ \\
\hline
\end{tabular}

Sumber: data diolah, 2018

Tabel 2: Influence Matrix

\begin{tabular}{|c|c|c|c|c|c|c|c|c|c|c|c|c|c|c|c|c|c|c|}
\hline & A1-1 & A1-2 & A1-3 & A1-4 & A1-5 & A1-6 & A2-1 & A2-2 & $A 2-3$ & A2-4 & A3-1 & A3-2 & A3-3 & A3-4 & A4-1 & A5-1 & A6-1 & Total D \\
\hline A1-1 & 0.34 & 0.38 & 0.42 & 0.47 & 0.44 & 0.38 & 0.44 & 0.41 & 0.40 & 0.36 & 0.39 & 0.41 & 0.44 & 0.40 & 0.39 & 0.38 & 0.38 & $\begin{array}{l}6.83 \\
\end{array}$ \\
\hline A1-2 & 0.38 & 0.31 & 0.41 & 0.44 & 0.41 & 0.36 & 0.41 & 0.41 & 0.39 & 0.34 & 0.38 & 0.39 & 0.42 & 0.38 & 0.36 & 0.35 & 0.37 & 6.50 \\
\hline A1-3 & 0.42 & 0.39 & 0.37 & 0.47 & 0.45 & 0.38 & 0.45 & 0.43 & 0.44 & 0.36 & 0.41 & 0.42 & 0.44 & 0.42 & 0.41 & 0.40 & 0.39 & 7.04 \\
\hline A1-4 & 0.38 & 0.36 & 0.39 & 0.37 & 0.41 & 0.35 & 0.41 & 0.40 & 0.39 & 0.33 & 0.37 & 0.39 & 0.41 & 0.37 & 0.36 & 0.34 & 0.36 & 6.38 \\
\hline A1-5 & 0.35 & 0.34 & 0.38 & 0.42 & 0.33 & 0.33 & 0.39 & 0.38 & 0.37 & 0.31 & 0.35 & 0.36 & 0.38 & 0.35 & 0.34 & 0.33 & 0.34 & 6.06 \\
\hline A1- 6 & 0.31 & 0.30 & 0.33 & 0.36 & 0.34 & 0.24 & 0.34 & 0.33 & 0.32 & 0.27 & 0.30 & 0.31 & 0.33 & 0.31 & 0.30 & 0.29 & 0.31 & 5.30 \\
\hline A2-1 & 0.36 & 0.34 & 0.39 & 0.42 & 0.40 & 0.33 & 0.33 & 0.38 & 0.37 & 0.31 & 0.35 & 0.36 & 0.38 & 0.35 & 0.34 & 0.33 & 0.34 & 6.08 \\
\hline A2-2 & 0.31 & 0.30 & 0.33 & 0.37 & 0.35 & 0.29 & 0.36 & 0.30 & 0.35 & 0.29 & 0.32 & 0.33 & 0.35 & 0.33 & 0.32 & 0.31 & 0.32 & 5.53 \\
\hline A2.3 & 0.32 & 0.31 & 0.34 & 0.39 & 0.35 & 0.29 & 0.36 & 0.37 & 0.30 & 0.29 & 0.33 & 0.35 & 0.36 & 0.33 & 0.32 & 0.31 & 0.33 & 5.63 \\
\hline A2-4 & 0.32 & 0.32 & 0.35 & 0.38 & 0.36 & 0.30 & 0.35 & 0.36 & 0.34 & 0.25 & 0.32 & 0.33 & 0.37 & 0.33 & 0.32 & 0.31 & 0.32 & 5.65 \\
\hline A3-1 & 0.32 & 0.32 & 0.35 & 0.38 & 0.37 & 0.30 & 0.36 & 0.37 & 0.36 & 0.29 & 0.28 & 0.34 & 0.37 & 0.33 & 0.32 & 0.32 & 0.32 & 5.70 \\
\hline A3-2 & 0.35 & 0.33 & 0.37 & 0.41 & 0.39 & 0.32 & 0.38 & 0.39 & 0.39 & 0.31 & 0.35 & 0.31 & 0.39 & 0.35 & 0.34 & 0.34 & 0.34 & 6.07 \\
\hline A3-3 & 0.39 & 0.36 & 0.41 & 0.44 & 0.42 & 0.35 & 0.41 & 0.42 & 0.41 & 0.36 & 0.40 & 0.41 & 0.36 & 0.38 & 0.37 & 0.36 & 0.37 & 6.60 \\
\hline A3-4 & 0.33 & 0.32 & 0.36 & 0.39 & 0.38 & 0.31 & 0.37 & 0.37 & 0.37 & 0.31 & 0.34 & 0.35 & 0.37 & 0.30 & 0.35 & 0.33 & 0.33 & 5.87 \\
\hline A4-1 & 0.37 & 0.34 & 0.40 & 0.43 & 0.41 & 0.34 & 0.41 & 0.41 & 0.40 & 0.34 & 0.37 & 0.38 & 0.40 & 0.39 & 0.31 & 0.36 & 0.36 & 6.41 \\
\hline A5-1 & 0.33 & 0.31 & 0.36 & 0.37 & 0.36 & 0.30 & 0.36 & 0.36 & 0.35 & 0.29 & 0.33 & 0.34 & 0.36 & 0.34 & 0.33 & 0.27 & 0.32 & 5.66 \\
\hline A6-1 & 0.35 & 0.34 & 0.39 & 0.41 & 0.39 & 0.32 & 0.38 & 0.38 & 0.37 & 0.32 & 0.35 & 0.37 & 0.39 & 0.36 & 0.35 & 0.34 & 0.30 & 6.11 \\
\hline Total R & 5.94 & 5.66 & 6.35 & 6.93 & 6.57 & 5.48 & 6.51 & 6.45 & 6.31 & 5.31 & 5.94 & 6.18 & 6.50 & 6.01 & 5.81 & 5.65 & 5.79 & \\
\hline
\end{tabular}

Sumber: data diolah, 2018

Hasil metode DEMATEL pada penelitian ini dapat di lihat seperti pada tabel 2 di atas. Influence Matrix dibawah dimana nilai treshold value ditentukan nilai rata rata dari hasil tabel mmult yaitu 0.366 . Nilai kolom matriks yang bernilai sama atau lebih besar dari nilai treshold value pada matriks mmult tidak diberi warna, sementara nilai lebih kecil diberi warna merah. Nilai yang dibawah 0.366 berarti menunjukan bahwa dua kriteria / subkriteria tersebut tidak saling berkaitan

Tahapan terakhir pada DEMATEL adalah menghitung nilai Dispatcher (D) dan Receiver (R). Kriteria yang termasuk dalam kelompok $D$ adalah kriteria yang dikategorikan sebagai pemberi dampak (mempengaruhi kriteria lain) dan dapat 
disebut sebagai kriteria dominan (dijadikan prioritas dalam evaluasi). Kriteria yang termasuk dalam kelompok $\mathrm{R}$ tidak dominan jika dibandingkan dengan kriteria kelompok $\mathrm{D}$, sehingga tidak perlu diprioritaskan dalam pengambilan keputusan.

Nilai indeks total kekuatan pengaruh diberikan dan diterima oleh suatu kriteria/ subkriteria keputusan $(D+R)$, dan nilai kecenderungan tingkat pengaruh dari masing-masing kriteria / subkriteria keputusan (D-R), apabila nilai (D-R) positif maka kriteria / subkriteria keputusan tersebut cenderung lebih mempengaruhi, apabila nilai (D-R) negatif, sebaliknya kriteria / subkriteria tersebut cenderung lebih dipengaruhi kriteria / subkriteria lain. Nilai $(D+R)$ dan (D-R) dapat di lihat pada tabel 3 dan tabel 4 di bawah ini.

Tabel 3: Nilai (D+R) dan (D-R) Kriteria Keputusan

\begin{tabular}{|l|c|c|c|c|}
\hline Kriteria & D & R & D+R & D-R \\
\hline Kemampuan Internal \& Keuangan & 11.71 & 10.94 & 22.64 & 0.77 \\
\hline Kemampuan Teknis & 11.56 & 11.15 & 22.71 & 0.41 \\
\hline Kemampuan Organisasi & 11.67 & 11.41 & 23.08 & 0.25 \\
\hline Komitmen Quality Assurance & 10.55 & 11.24 & 21.79 & -0.70 \\
\hline Komitmen Keselamatan dan Kesehatan Kerja & 10.29 & 10.40 & 20.68 & -0.11 \\
\hline Harga & 9.14 & 9.77 & 18.91 & -0.63 \\
\hline
\end{tabular}

Sumber: Hasil Olah Data

Tabel 4: Nilai (D+R) dan (D-R) Subkriteria Keputusan

\begin{tabular}{|l|c|c|c|c|}
\hline Kriteria & D & R & D+R & D-R \\
\hline Klasifikasi & 6.83 & 5.94 & 12.77 & 0.89 \\
\hline Kemampuan Keuangan & 6.50 & 5.66 & 12.16 & 0.85 \\
\hline Reputasi & 7.04 & 6.35 & 13.39 & 0.68 \\
\hline Kemampuan Melaksanakan Paket & 6.38 & 6.93 & 13.30 & -0.55 \\
\hline Kinerja Proyek Sebelumnya & 6.06 & 6.57 & 12.63 & -0.51 \\
\hline Nilai Proyek Sejenis & 5.30 & 5.48 & 10.78 & -0.18 \\
\hline Pengalaman Proyek yang sejenis & 6.08 & 6.51 & 12.59 & -0.44 \\
\hline Metode Pelaksanaan & 5.53 & 6.45 & 11.98 & -0.92 \\
\hline Jadwal Pelaksanaan & 5.63 & 6.31 & 11.95 & -0.68 \\
\hline Kapasitas Peralatan & 5.65 & 5.31 & 10.96 & 0.33 \\
\hline Organisasi Proyek & 5.70 & 5.94 & 11.64 & -0.23 \\
\hline Manajemen Proyek & 6.07 & 6.18 & 12.25 & -0.11 \\
\hline SDM & 6.60 & 6.50 & 13.10 & 0.10 \\
\hline Quality Control & 5.87 & 6.01 & 11.88 & -0.14 \\
\hline Komitmen pada Quality Assurance & 6.41 & 5.81 & 12.22 & 0.60 \\
\hline Komitmen pada K3 & 5.66 & 5.65 & 11.31 & 0.01 \\
\hline Harga & 6.11 & 5.79 & 11.90 & 0.32 \\
\hline
\end{tabular}

Sumber: Hasil Olah Data

Dari hasil Tabel 3. nilai (D+R) dan (D-R) Subkriteria keputusan menunjukkan bahwa kriteria kemampuan internal dan keuangan memberikan pengaruh paling besar terhadap kriteria lainnya dengan nilai 0.77 . Sedangkan kriteria komitmen quality assurance menerima dampak pengaruh yang paling besar dari kriteria lainnya yaitu dengan nilai -0.70 . 
Sedangkan dari hasil Tabel 4. nilai $(D+R)$ dan $(D-R)$ kriteria keputusan menunjukkan bahwa subkriteria klasifikasi dan kemampuan keuangan memberikan pengaruh paling besar terhadap subkriteria lainnya dengan nilai 0.89 dan 0.85 . Sedangkan subkriteria metode pelaksanaan dan jadwal pelaksanaan menerima dampak pengaruh yang paling besar dari subkriteria lainnya yaitu dengan nilai -0.92 dan -0.68 .

Sedangkan model analisa keterkaitan keputusan seperti di tunjukkan pada gambar 1 dibawah, bahwa kriteria kemampuan internal dan keuangan mempengaruhi kriteria keputusan lain dengan nilai indeks 0.77 , kriteria kemampuan teknis juga mempengaruhi kriteria lain dengan nilai indeks 0.41 . Selain kedua kriteria tersebut kriteria kemampuan organisasi juga mempengaruhi kriteria keputusan lain dengan nilai indeks 0.25 . Ketiga kriteria keputusan tersebut berpengaruh terhadap kriteria lain khususnya dalam pemilihan Engineering Contractor pada proyek dana hibah energi terbarukan di Lembaga " $Y$ ".

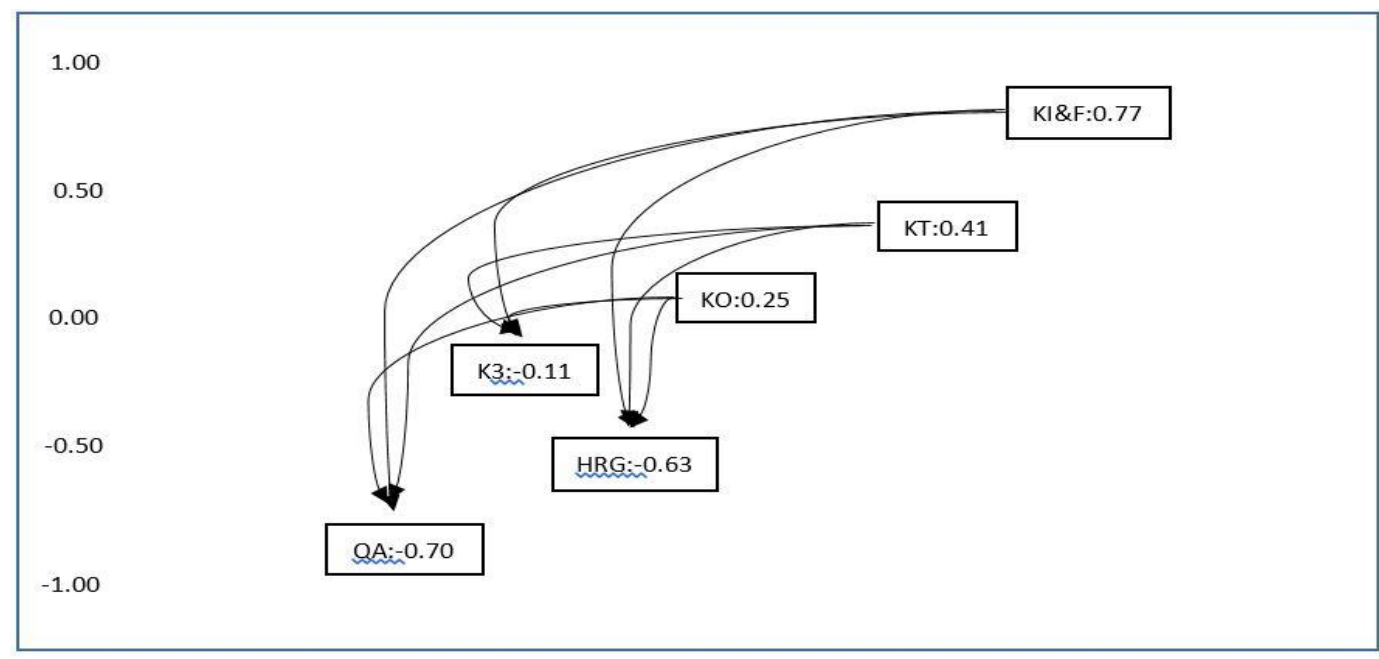

Gambar 1: Model Analisa Keterkaitan Antar Kriteria

Pada Gambar 2 dibawah menunjukkan bahwa subkriteria klasifikasi lebih mempengaruhi subkriteria lain dengan nilai indeks 0.89 , dilanjutkan dengan subkriteria kemampuan keuangan mempengaruhi subkriteria lain dengan nilai indeks 0.86 . Subkriteria ketiga yang mempengaruhi adalah subkriteria reputasi dengan nilai indeks sebesar 0.68 , disusul dengan pada subkriteria komitmen quality assurance dengan nilai indeks 0.6 , subkriteria kapasitas peralatan (software) dengan nilai indeks 0.33 , subkriteria harga dengan nilai indeks 0.32 , subkriteria sumber daya manusia (SDM) dengan nilai indeks 0.1 dan sedikit pengaruh pada subkriteria komitmen keselamatan dan kesehatan kerja (K3) dengan nilai indeks 0.01 . Dari hasil nilai keterkaitan subkriteria tersebut dapat digunakan sebagai masukan tim evaluasi dalam 
membandingkan subkriteria keputusan pemilihan engineering contractor pada proyek sejenis, sebab beberapa subkriteria tersebut berpengaruh untuk meningkatkan kualitas evaluasi pemilihan engineering contractor pada proyek sejenis, khususnya pada proyek-proyek yang ada di lembaga " $Y$ ".

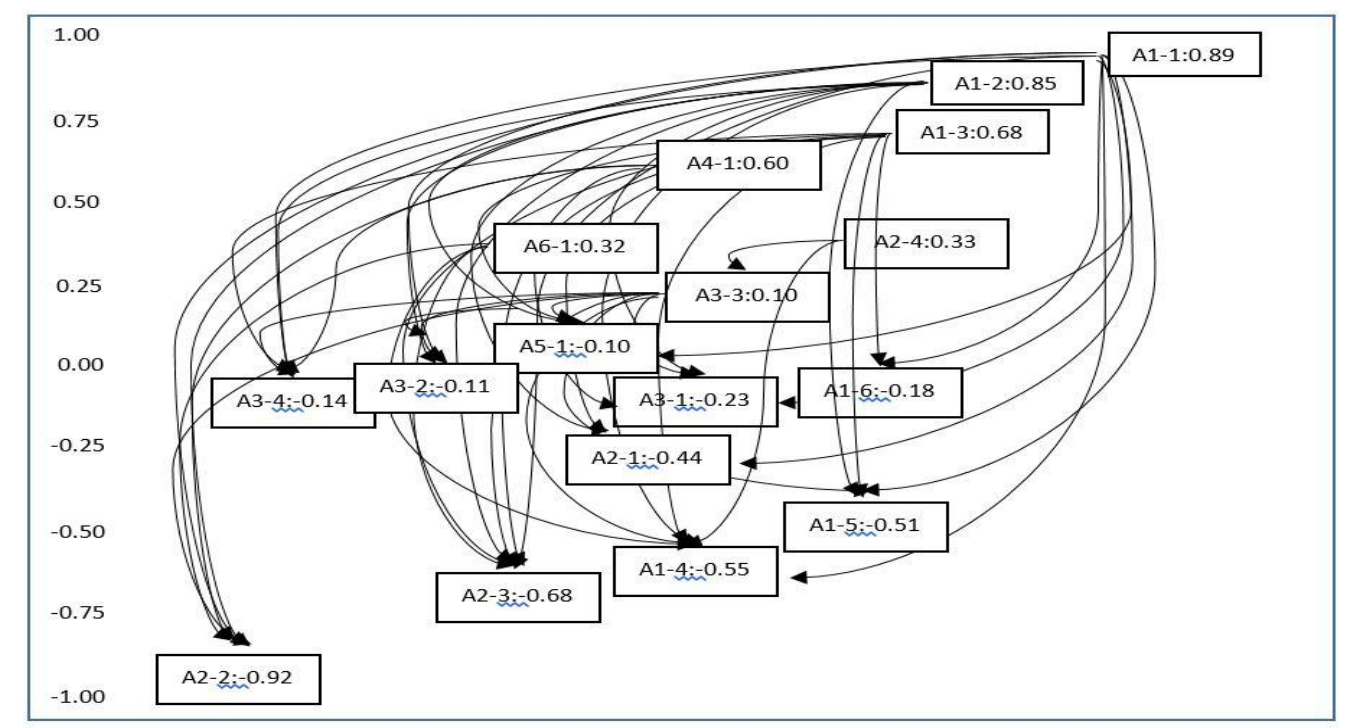

Gambar 2: Model Analisa Keterkaitan Antar Subkriteria

Selanjutnya akan di buat konstruksi model keterkaitan di ANP seperti terlihat pada Gambar 3. Model Sistem Pemilihan Engineering Contractor dengan Metode ANP seperti di bawah ini.

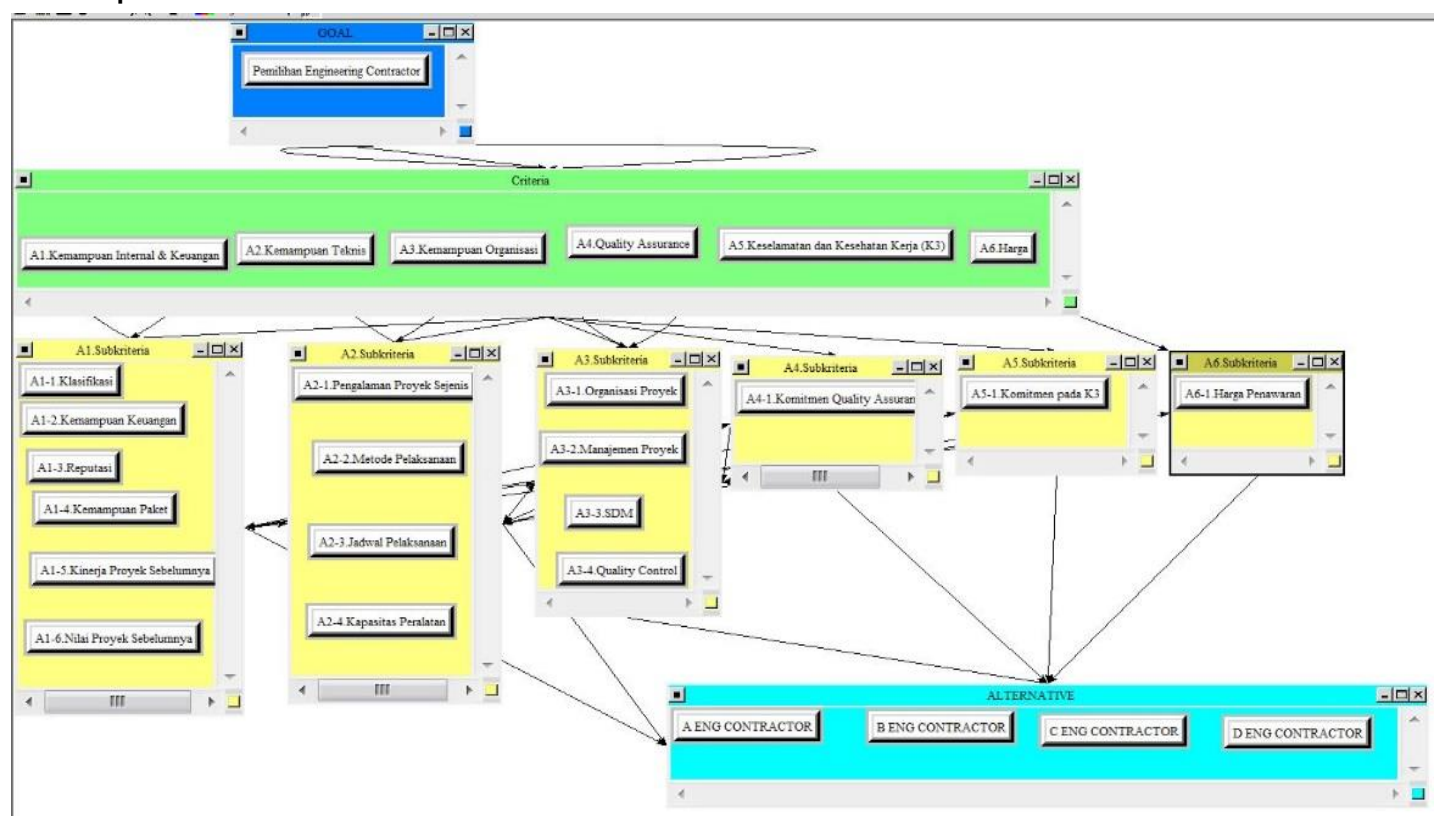

Gambar 3: Model Sistem Pemilihan Engineering Contractor dengan ANP

Setelah model network telah dibuat maka selanjutnya dapat ditentukan nilai pairwise comparison (perbandingan berpasangan) antar kriteria dan antar alternatif. Nilai pairwise comparison tersebut didapatkan dengan menggunakan kuisioner. Nilai bobot prioritas tiap kategori yang didapatkan berdasarkan nilai pairwise comparison 
akan diperbandingkan untuk mendapatkan nilai bobot prioritas yang akhir dengan menggunakan software Super decision.

Pada analisa kriteria keputusan, kriteria kemampuan internal dan keuangan memiliki bobot yang paling tinggi dengan nilai bobot adalah $34.36 \%$, yang kedua adalah kriteria kemampuan teknis dengan nilai bobot $28.38 \%$, selanjutnya kemampuan organisasi dengan nilai bobot $16.75 \%$ dan di tempat ketiga yaitu komitmen quality assurance adalah $8.05 \%$, di susul dengan keselamatan dan kesehatan kerja dan harga. Lebih jelasnya hasil nilai bobot kriteria keputusan tersebut dapat diliat pada gambar 3 bobot kriteria keputusan di bawah ini.

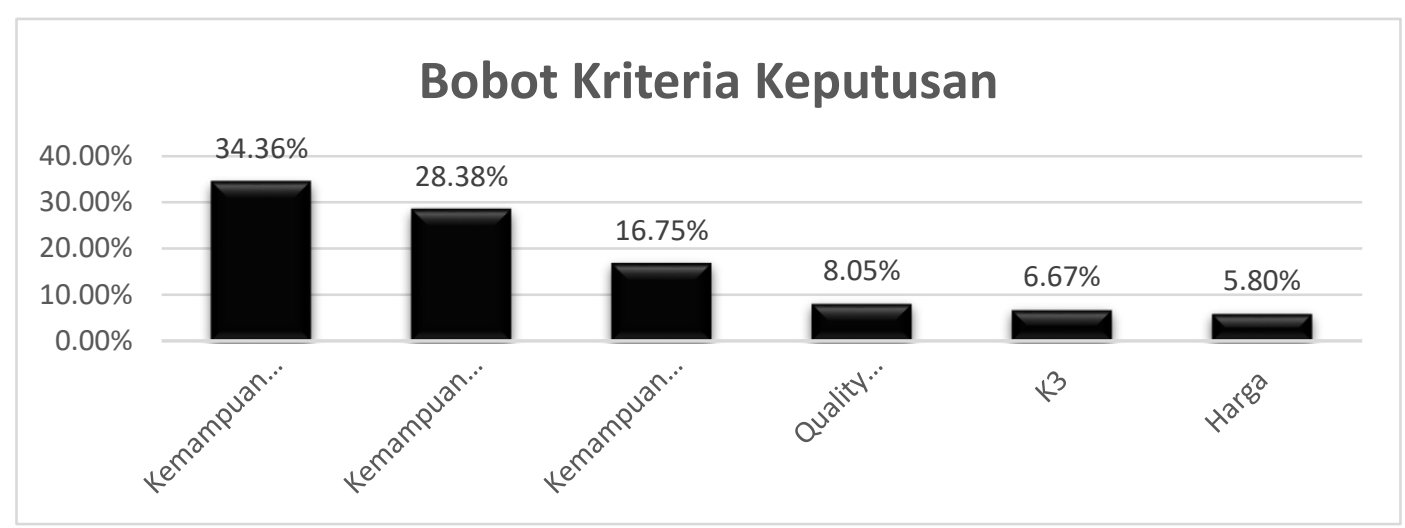

Gambar 4: Bobot Kriteria Keputusan

Hasil pembobotan subkriteria keputusan pada gambar 4 bobot subkriteria keputusan di bawah menunjukkan subkriteria klasifikasi $13.8 \%$ tertinggi dengan nilai sebesar $12.79 \%$, tertinggi kedua adalah kemampuan keuangan $8.84 \%$, disusul dengan subkriteria pengalaman proyek yang sejenis dan metode pelaksanaan. Subkriteria keputusan dengan nilai terendah adalah kinerja proyek sebelumnya dan nilai proyek sebelumnya dengan skor adalah $1.63 \%$.

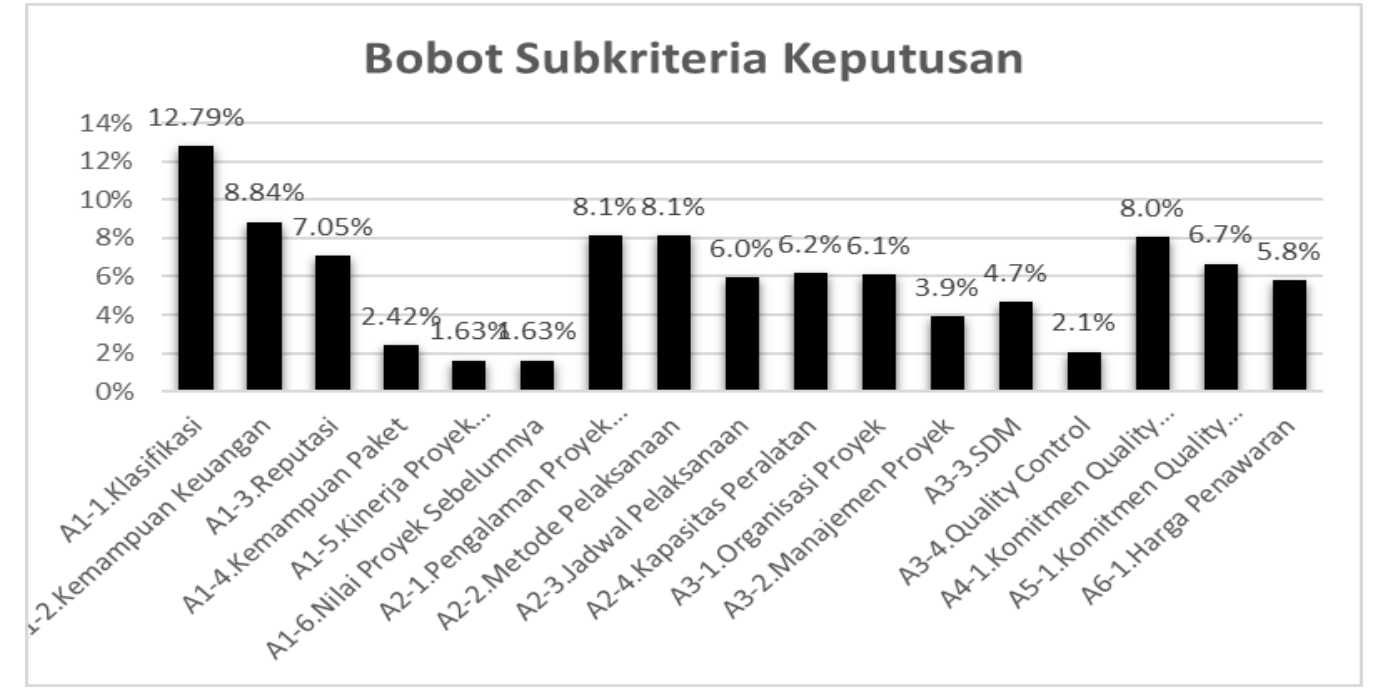

Gambar 5: Bobot SubKriteria Keputusan 
Hasil penilaian engineering contractor menunjukkan engineering contractor A mendominasi hampir di setiap subkriteria keputusan. Misalkan pada subkriteria kemampuan keuangan, metode pelaksanaan, kapasitas peralatan, organisasi proyek, manajemen proyek dan Sumber daya manusia, komitmen quality assurance dimana engineering contractor A mempunyai skor yang lebih tinggi dibandingkan engineering contractor lainnya. Skor total terendah adalah engineering contrator D dimana subkriteria keputusan dengan nilai kecil pada kinerja proyek sebelumnya, metode pelaksanaan, organisasi proyek, Sumber Daya Manusia dan komitmen pada Quality Assurance.

Tabel 5: Penilaian Engineering Contractor

\begin{tabular}{|c|c|c|c|c|c|c|c|c|c|}
\hline \multirow[t]{2}{*}{ Subkriteria } & \multirow[t]{2}{*}{ Bobot } & \multicolumn{2}{|c|}{$\begin{array}{l}\text { Eng. } \\
\text { Contractor A }\end{array}$} & \multicolumn{2}{|c|}{$\begin{array}{l}\text { Eng. } \\
\text { Contractor B }\end{array}$} & \multicolumn{2}{|c|}{$\begin{array}{l}\text { Eng. } \\
\text { Contractor C }\end{array}$} & \multicolumn{2}{|c|}{$\begin{array}{l}\text { Eng. } \\
\text { Contractor D }\end{array}$} \\
\hline & & Nilai & Total & Nilai & Total & Nilai & Total & Nilai & Total \\
\hline Klasifikasi & $12.79 \%$ & 8.60 & 1.10 & 8.40 & 1.07 & 8.20 & 1.05 & 8.20 & 1.05 \\
\hline Kemampuan Keuangan & $8.84 \%$ & 9.00 & 0.80 & 5.00 & 0.44 & 6.40 & 0.57 & 5.40 & 0.48 \\
\hline Reputasi & $7.05 \%$ & 8.40 & 0.59 & 4.60 & 0.32 & 6.00 & 0.42 & 4.80 & 0.34 \\
\hline $\begin{array}{l}\text { Kemampuan } \\
\text { Melaksanakan Paket }\end{array}$ & $2.42 \%$ & 7.80 & 0.19 & 4.60 & 0.11 & 6.00 & 0.14 & 5.20 & 0.13 \\
\hline $\begin{array}{l}\text { Kinerja Proyek } \\
\text { Sebelumnya }\end{array}$ & $1.63 \%$ & 8.00 & 0.13 & 5.40 & 0.09 & 6.00 & 0.10 & 4.60 & 0.08 \\
\hline Nilai Proyek Sejenis & $1.63 \%$ & 6.20 & 0.10 & 5.40 & 0.09 & 6.00 & 0.10 & 4.20 & 0.07 \\
\hline $\begin{array}{l}\text { Pengalaman Proyek yang } \\
\text { Sejenis }\end{array}$ & $8.1 \%$ & 5.20 & 0.42 & 5.00 & 0.41 & 6.00 & 0.49 & 4.20 & 0.34 \\
\hline Metode Pelaksanaan & $8.1 \%$ & 8.00 & 0.65 & 4.60 & 0.37 & 5.60 & 0.46 & 3.80 & 0.31 \\
\hline Jadwal Pelaksanaan & $6.0 \%$ & 8.00 & 0.48 & 4.60 & 0.27 & 5.60 & 0.33 & 4.40 & 0.26 \\
\hline $\begin{array}{l}\text { Kapasitan Peralatan } \\
\text { (Software) }\end{array}$ & $6.2 \%$ & 8.20 & 0.51 & 4.00 & 0.25 & 5.20 & 0.32 & 4.20 & 0.26 \\
\hline Organisasi Proyek & $6.1 \%$ & 8.20 & 0.50 & 4.20 & 0.26 & 4.20 & 0.26 & 3.80 & 0.23 \\
\hline Manajemen Proyek & $3.9 \%$ & 8.00 & 0.31 & 4.20 & 0.16 & 4.40 & 0.17 & 3.80 & 0.15 \\
\hline SDM & $4.7 \%$ & 8.20 & 0.38 & 5.20 & 0.24 & 4.80 & 0.22 & 4.20 & 0.20 \\
\hline Quality Control & $2.1 \%$ & 7.80 & 0.16 & 4.00 & 0.08 & 4.80 & 0.10 & 4.00 & 0.08 \\
\hline $\begin{array}{l}\text { Komitmen pada Quality } \\
\text { Assurance }\end{array}$ & $8.0 \%$ & 8.00 & 0.64 & 4.60 & 0.37 & 4.80 & 0.39 & 4.00 & 0.32 \\
\hline Komitmen pada $\mathrm{K} 3$ & $6.7 \%$ & 7.60 & 0.51 & 4.40 & 0.29 & 4.60 & 0.31 & 4.00 & 0.27 \\
\hline Harga Penawaran & $5.8 \%$ & 6.20 & 0.36 & 5.00 & 0.29 & 3.40 & 0.20 & 3.40 & 0.20 \\
\hline Total & & 7.83 & & 5.13 & & 5.62 & & 4.75 & \\
\hline
\end{tabular}

Analisa peringkat engineering contractor di tunjukkan seperti gambar 6 dibawah dimana engineering contractor A sebagai engineering contractor peringkat pertama dengan skor sebesar 7.83 dan peringkat kedua adalah engineering contractor $\mathrm{C}$ dengan skor 5.62, di susul oleh engineering contractor $\mathrm{B}$ dengan skor 5.13 dan terakhir adalah engineering contractor $\mathrm{D}$ dengan skor 4.75. Berdasarkan hasil ini maka engineering contractor A sebagai alternatif keputusan untuk mengerjakan proyek-proyek dana hibah energi terbarukan di lembaga " $Y$ ". 


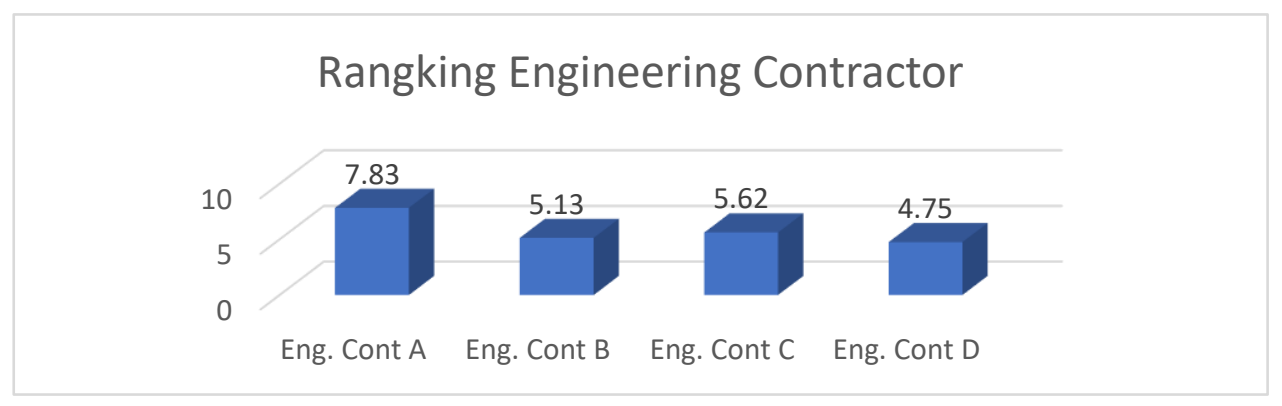

Gambar 6: Analisa Peringkat Engineering Contractor

\section{Kesimpulan}

Berdasarkan hasil penelitian dan analisa serta interprestasi data yang dilakukan, maka dapat disimpulkan bahwa: (1) Analisa korelasi interdependensi menggunakan metode DEMATEL memberikan gambaran mengenai jaringan antar kriteria /subkriteria keputusan, dimana subkriteria klasifikasi paling besar mempengaruhi subkriteria lain dengan nilai indeks sebesar 0.89; (2) Hasil pembobotan menggunakan metode ANP menunjukan bahwa subkriteria klasifikasi memiliki bobot tertinggi dari pada subkriteria yang lain, dengan nilai bobot 12.79 hal tersebut menandakan tim evaluasi lebih memprioritaskan kriteria internal atau administrasi sesuai dengan peraturan yang berlaku untuk jasa perencanaan di Indonesia; (3) Dari keseluruhan proses analisa menunjukkan bahwa engineering contractor A sebagai peringkat pertama dengan nilai sebesar 7.83 , sedangkan peringkat kedua adalah engineering contractor $C$ Dengan nilai 5.62. Selanjutanya berurutan adalah engineering contractor B dan D. Dari rancangan model sistem pengambilan keputusan pemilihan engineering contractor ini, pemenang tender memiliki kualitas penawaran tidak hanya mempertimbangkan aspek teknis dan harga tetapi ada aspek kemampuan internal dan keuangan yang sangat mempengaruhi pengambilan keputusan terutama yang sesuai dengan kondisi pada proyek proyek yang ada di lingkungan lembaga " $Y$ ".

\section{Saran}

Adapun saran yang diberikan dalam penelitian ini adalah: (a) Evaluasi engineering contractor di Lembaga " $Y$ " perlu menambahkan kriteria dan subkriteria dalam sistem evaluasi engineering contrcator yaitu kriteria komitmen quality asssurance dan subkriteria seperti reputasi, kinerja proyek sebelumnya dan nilai proyek sebelumnya untuk meningkatkan kinerja dan performance proyek khususnya dalam perencanaan desain proyek sesuai dengan kebutuhan dan harapan dari 
Lembaga " $Y$ "; (b) Lembaga " $Y$ " dalam pengambilan keputusan perlu mempertimbangkan kriteria kemampuan internal dan keuangan dan kriteria kemampuan teknis dimana kriteria tersebut memberikan pengaruh paling besar terhadap kriteria lainnya. Sedangkan kriteria komitmen quality assurance dan harga adalah kriteria yang menerima dampak terbesar dibandingkan kriteria lainnya. Dengan pertimbangan kriteria tersebut diharapkan bisa meminimalisasi terjadinya resiko keterlambatan proyek atau bahkan kegagalan proyek; (c) Lembaga " $Y$ " dalam pengambilan keputusan perlu mempertimbangkan subkriteria klasifikasi dan kemampuan keuangan engineering contractor dimana subkriteria tersebut memberikan pengaruh paling besar terhadap subkriteria lainnya. Sedangkan subkriteria metode pelaksanaan dan jadwal pelaksanaan adalah subkriteria yang menerima dampak terbesar dibandingkan subkriteria lainnya.

\section{Daftar Referensi}

Ng, S. T., \& Skitmore, M. 1999. Client and Consultant Perpectives of Prequalification Criteria. Building and Environment, 34, 607-625.

Peraturan Presiden No 70 tahun 2012 dan Peraturan Kementerian Pekerjaan Umum No 08/PRT/M/2011.

Singh, D., \& Tiong, R.L. 2005. A Fuzzy Decision Framework for Contractor Selection. Journal of Construction Engineering and Management, 62,62-70.

Saaty.T. L. 1994. How to make a decision: The Analytic Network Process. Decision Analysis, 24, 19-43.

Saaty. 1999. Fundamental of The Analytic Network Process. Decision Making, 12-14.

Sevkli, M., Oztekin, A., Uysal, O., Torlak, G., Turkyilmaz, A., \& Delen, D.2012. Development of A Fuzzy ANP Based SWOT Analysis for The Airline Industry In Turkey. Expert System with Applications, 39 (1), 14-24.

Shieh, J. I., Wu, H. H. and Huang, K. K. (2010). A DEMATEL method in identifying key success factors of hospital service quality. Knowledge-Based Systems, 23, 277282.

Swami, S. 2013. Executive Functions and Decision Making: A Managerial Review. International Journal of Project Management, 25, 203-212. 